JKM (Jurnal Kebidanan Malahayati),Vol 7,No.3.Juli 2021,

ISSN (Print) 2476-8944 ISSN (Online) 2579-762X, Hal 471-480

\title{
KARAKTERISTIK GESTASIONAL DAN STANDAR OPERASIONAL PROSEDUR (SOP) IBU BERSALIN DENGAN SECTIO CAESARIA PADA MASA PANDEMI COVID-19
}

\author{
Putu Dian Prima Kusuma Dewi ${ }^{1 *}$, Lina Anggaraeni Dwijayanti², Kadek Ayu Suarmini ${ }^{3}$, \\ Ni Made Karlina Sumiari Tangkas ${ }^{4}$, Indrie Lutfiana ${ }^{5}$, Dewa Ayu Dian Purnami ${ }^{6}$ \\ ${ }^{1 *}$ Prodi S1 Kebidanan dan Profesi Bidan, D3 Kebidanan, STIKes Buleleng \\ ${ }^{2}$ RSUD Sanjiwani Gianyar \\ *Korespondensie Email: dian_pkd@yahoo.co.id
}

\section{ABSTRACT GESTATIONAL CHARACTERISTICS AND STANDARD OPERATIONAL PROCEDURES (SOP) FOR MATERNAL WITH SECTION CAESARIA DURING THE COVID-19 PANDEMIC}

Background Covid-19 is a disease that can be transmitted through droplets, with signs and symptoms, namely coughing, shortness of breath, hyperthermia and others. The Covid-19 pandemic period is something that really needs to be considered, especially for maternity mothers who will have a caesarean section, by screening a good covid-19 protocol before a caesarean section is carried out.

Purpose of this study was to determine the gestational characteristics of mothers giving birth with Sectio Caesaria during the Covid-19 pandemic in the Central Surgical Installation Room (IBS) of the Sanjiwani Hospital, Gianyar.

Methods This study uses a mix method design, where quantitative data uses a cross sectional approach to the type of secondary data, namely Medical Records. The qualitative data used in-depth interviews involving the head of the room and the Head of Nursing at the Sanjiwani Hospital consisting of 4 doctors, midwives and nurses. The data were analyzed by univariate analysis with Stata SE 12 software. This study used total sampling in the period March-September 2020 with a total of 102 mothers who gave birth by cesarean section.

Results of the study were obtained from 102 respondents with an average age of 29.77 years, with high school education, namely 75 people (70\%), 55 people not working (52\%), medical indications 82 people (80.39\%), complaints of vaginal discharge (KPD) were 33 people (32.35\%), positive rapid test 37 people (36.27\%), and positive PCR swab results were 33 people (32.35\%).

Conclusion The policy is that all pregnant women must undergo a rapid test and PCR test before the delivery process is carried out

Suggestions The regulation of maternity services during the COVID-19 pandemic is more about screening, namely mandatory rapid tests and PCR tests. Handling with strict health protocol level 3 to break the chain of virus transmission.

Key words: Sectio Caesaria, Covid-19, SOP

\section{ABSTRAK}

Latar Belakang Covid-19 merupakan penyakit yang dapat ditularkan melalui droplet, dengan tanda dan gejala yaitu batuk, sesak, hipertermi dan lain-lain. Masa pandemi Covid-19 merupakan hal yang sangat perlu diperhatikan terutama pada ibu bersalin yang akan dilakukan tindakan sectio caesarea, dengan melakukan skrining protocol covid-19 yang baik sebelum dilakukan tindakansectio caesarea.

Tujuan penelitian ini adalah untuk mengetahui karakteristik gestasional pada ibu bersalin dengan Sectio Caesaria pada masa pandemi Covid-19 di Ruang Instalasi Bedah Sentral (IBS) RSUD Sanjiwani Gianyar.

Metode Penelitian ini menggunakan rancangan mixmethod, dimana data kuantitatif menggunakan pendekatan cross sectional pada jenis data sekunder yaitu Rekam Medis. Data kualitatif menggunakan wawancara mendalam yang melibatkan kepala ruangan dan Kabag Keperawatan RSUD Sanjiwani yang terdiri dari dokter, bidan dan perawat yang berjumlah 4 orang. Data dianalisis dengan analisis univariat dengan software Stata SE 12. Penelitian ini menggunakan total sampling pada periode Maret-September 2020 dengan total 102 orang ibu bersalin dengan tindakan SC.

Hasil penelitian didapatkan dari 102 responden rata-rata pada umur 29,77 tahun, berpendidikan SMA yaitu 75 orang $(70 \%)$, tidak bekerja sebanyak 55 orang $(52 \%)$, indikasi medis sebesar 82 orang $(80.39 \%)$, 


\section{Putu Dian Prima Kusuma Dewi, Lina Anggaraeni Dwijayanti, Kadek Ayu Suarmini, Ni Made Karlina Sumiari Tangkas, Indrie Lutfiana, Dewa Ayu Dian Purnami}

keluhan keluar air pervaginam (KPD) yaitu 33 orang (32.35\%), rapid test positif 37 orang (36.27\%), dan hasil swab PCR positif sebanyak 33 orang (32.35\%).

Kesimpulan Kebijakan yang dilakukan bahwa seluruh ibu hamil wajib dilakukan rapid test dan PCR test sebelum dilakukan proses tindakan persalinan

Saran Regulasi layanan ibu bersalin pada masa pandemi COVID 19 ini lebih pada skrining yaitu wajib rapid test dan test PCR. Penanganan dengan protokol kesehatan yang ketat level 3 untuk memutus rantai penularan virus.

Kata Kunci : Sectio Caesaria, Covid-19, SOP

\section{PENDAHULUAN}

World Health Organization (WHO) telah mengumumkan Coronavirus Disease-19 (Covid-19) sebagai Public Health Eemergency of International Concern dan akhirnya ditetapkan sebagai Pandemi pada tanggal 11 Maret 2020. Covid-19 adalah penyakit jenis baru (emerging disease) yang muncul pertama kali di Wuhan, China pada tanggal 31 Desember 2019 (WHO, 2020). Penyakit ini disebabkan oleh virus Sars-CoV-2 (severe acute respiratory syndrome coronavirus 2) yang dapat menyebabkan gejala penyakit dari ringan maupun berat. Tanda dan gejala umum infeksi Covid-19 antara lain gejala gangguan pernapasan akut seperti demam, batuk dan sesak napas. Masa inkubasi rata-rata 5-6 hari dengan masa inkubasi terpanjang 14 hari. Pada kasus Covid-19 yang berat dapat menyebabkan pneumonia, sindrom pernapasan akut, gagal ginjal dan bahkan kematian (Kemenkes, 2020).

Secara global kasus Covid-19 yang dilaporkan hingga tanggal 3 Juni 2021 sebanyak 172 juta kasus dengan angka kematian 3.69 juta kasus. Kasus tertinggi ditemukan di Amerika Serikat disusul oleh Brasil, India, Rusia dan Afika Selatan. Indonesia, melaporkan penambahan jumlah kasus terkonfirmasi yang terus meningkat setiap harinya, hingga 3 Juni kasus bertambah cukup signifikan sebanyak 1,83 juta orang dengan jumlah pasien yang meninggal sebanyak 50.908 orang (Kemenkes, 2021). Laporan Dinas Kesehatan Provinsi Bali hingga tanggal 3 Juni 2021 melaporkan jumlah pasien yang terkonfirmasi positif sebanyak 47366 kasus, perawatan 543 orang $(1.15 \%)$ meninggal dan sebanyak 45.318 orang (95.68\%) sembuh, dan meninggal 1.505 orang (3.18\%) yang tersebar diseluruh kabupaten kota se Bali. (Dinkes Prov Bali, 2021)

Dalam situasi normal, kematian ibu dan kematian neonatal di Indonesia masih menjadi tantangan besar apalagi dalam situasi bencana. Saat ini, Indonesia sedang menghadapi bencana nasional non alam COVID-19 sehingga pelayanan kesehatan maternal dan neonatal menjadi salah satu layanan yang berdampak baik secara akses maupun kualitas. Demam tinggi yang terjadi akibat COVID-19 di trimester pertama kehamilan dapat meningkatkan risiko terjadinya cacat lahir pada anak.Virus yang menyebabkan COVID-19 berasal dari golongan virus yang sama dengan virus penyebab severe acute respiratory syndrome (SARS) dan Middle-East respiratory syndrome (MERS). Berdasarkan kejadian yang lalu, ibu hamil dengan SARS atau MERS juga berisiko lebih tinggi mengalami keguguran atau melahirkan bayi prematur (Nareza,Meva, 2020). Dikhawatirkan, hal ini menjadi menyebabkan adanya peningkatan morbiditas dan mortalitas ibu dan bayi baru lahir.

Coronavirus dilaporkan dapat menyebabkan masalah kesehatan bagi janin dan bayi termasuk hambatan pertumbuhan intrauterin, persalinan prematur, aborsi spontan, dan kematian perinatal (Schwartz and Graham, 2020; Karimi et al., 2021). Risiko terpapar COVID-19 lebih banyak pada trimester III (Karimi et al., 2021). Kasus kematian akibat COVID-19 pada ibu hamil terjadi menjalani operasi caesar $(58,3 \%)$, 25\% melahirkan melalui vagina, dan $16,7 \%$ pada persalinan prematur (Karimi et al., 2021). Menurut WHO (World Health Organization), standar operasi SC di sebuah negara adalah 5-15\%. Presentase SC sekitar $5 \%$ di Indonesia. Rumah sakit pemerintah rata-rata 11 persen, sementara di Rumah Sakit Swasta rata rata 30 persen, angka ini terus berkembang (Aini, 2009). Berbagai survei menemukan bahwa persentasi persalinan SC pada rumah sakit-rumah sakit dikota besar seperti Jakarta dan Bali berada jauh diatas angka tersebut. Secara umum, jumlah persalinan SC di rumah sakit pemerintah adalah sekitar 30-35\% dari total persalinan sedangkan di rumah sakit swasta jumlahnya sangat tinggi yaitu sekitar $30-80 \%$ dari total persalinan (Rasyid, 2009) .

Selama menghadapi pandemic COVID-19, setiap rumah sakit sudah mempersiapkan persalinan yang aman untuk ibu yang akan melahirkan. Setiap ibu yang akan melahirkan 


\section{JKM (Jurnal Kebidanan Malahayati),Vol 7,No.3.Juli 2021, \\ ISSN (Print) 2476-8944 ISSN (Online) 2579-762X, Hal 471-480}

diwajibkan melakukan rapid test untuk dilakukan screening COVID-19. Apabila hasil rapid test reaktif, ibu hamil akan ditempatkan diruangan isolasi untuk mencegah terjadinya penularan kepada pasien yg lain. Ibu hamil dengan test PCR positif akan dilakukan tindakan sectio caesaria dengan pertimbangan untuk mempercepat proses melahirkan dan meminimalisasi penularan COVID19.(Gugus Tugas Percepatan Penanganan COVID19, 2020).

Regulasi dan kebijakan untuk penanganan ibu bersalin dengan COVID-19 menjadi kajian menarik dan sangat bervariatif. Kajian tentang regulasi ibu bersalin di masa pandemic ini juga masih sangat terbatas. Regulasi layanan persalinan di masa pandemi ini saat ini dengan wajib rapid test, Jika didapatkan ibu bersalin dengan rapid test positif, maka rujuk ke RS rujukan COVID-19 atau RS mampu PONEK. Penolong persalinan di FKTP (fasilitas kesehata tingkat pertama) menggunakan APD level-2. Jika kondisi sangat tidak memungkinan untuk merujuk kasus ODP, PDP, terkonfirmasi COVID-19 atau hasil skrining rapid test positif, maka pertolongan persalinan hanya dilakukan dengan menggunakan APD level- 3 dan Ibu bersalin dilengkapi dengan delivery chamber. FKTP memberikan layanan persalinan tanpa penyulit kehamilan/persalinan atau tidak ada tanda bahaya atau bukan kasus ODP, PDP atau terkonfirmasi COVID-19 (Gugus Tugas Percepatan Penanganan COVID-19, 2020).

Rumah Sakit Sanjiwani Gianyar merupakan salah satu RS pemerintah di Provinsi Bali dengan jumlah kasus SC sampai tahun 2019 sebesr 379 kasus. RSUD Sanjiwani Gianyar mulai menerapkan pemeriksaan rapid ibu bersalin pada bulan April. jumlah kasus SC dari bulan Juli-September 2020 sebanyak 98 kasus. studi pendahuluan yang dilakukan di RSUD Sanjiwani Gianyar dari bulan April-September 2020 terdapat 25 ibu hamil yang melahirkan dengan sectio caesaria dengan indikasi suspect COVID-19 dan terkonfirmasi COVID19.Karakteristik gestational pada ibu bersalin di masa pandemi ini dapat memberikan pengetahuan dan wawasan serta gambaran layanan yang diberikan

\section{METODOLOGI PENELITIAN Rancangan/Desain Penelitian}

Penelitian ini menggunakan rancangan mixmethod. Rancangan penelitian deskriptif kuantitatif dengan Crossectional menggunakan data sekunder merupakan rancangan kuantitatif. Sedangkan rancangan kualitatif menggunakan rancangan deskriptif untuk menggali tentang kebijakan dan regulasi ibu bersalin pada masa pandemic COVID-19. Studi ini dipilih sebagai data dasar untuk mengkeksplor kondisi ibu bersalin dengan SC. Tujuan penelitian ini adalah untuk mengetahui karakteristik gestasional pada ibu bersalin dengan Sectio Caesaria pada masa pandemi Covid-19 di Ruang Instalasi Bedah Sentral (IBS) RSUD Sanjiwani Gianyar. Variabel akan dikaji menggunakan data sekunder pada data rekam medis ibu bersalin dengan Sectio Caesaria pada masa pandemi Covid-19 di RSUD Sanjiwani Gianyar Tahun 2020.

\section{Sumber Data}

Data sekunder diambil dari data ibu bersalin dengan tindakan SC di RSU Sanjiwani pada periode bulan Maret-September 2020 yang tercantum dalam rekam medis. Data primer diperoleh dari wawancara mendalam mengenai regulasi dan standar operasional prosedur yang diterapkan dalam penanganan ibu bersalin dengan Covid-19.

\section{Sasaran Penelitian}

Populasi target dalam penelitian ini adalah seluruh ibu bersalin dengan tindakan sectio caesarea di RSUD Sanjiwani Pada Bulan April sampai dengan September tahun 2020 sejumlah 102 orang responden.

Sampel Penelitian

Sampel dalam penelitian ini adalah seluruh ibu bersalin di Ruang IBS RSUD Sanjiwani Gianyar Tahun 2020. Sejumlah 102 responden yang termasuk kriteria inklusi pada penelitian ini yaitu ibu bersalin dengan tindakan SC di masa periode AprilSeptember 2020 .

\section{Teknik Sampling}

Teknik pengambilan sampel dalam penelitian ini menggunakan teknik non probability yaitu sampel jenuh atau sering disebut total sampling. Teknik total sampling adalah teknik penetapan sampel dengan cara mengambil seluruh anggota populasi sebagai responden atau sampel. Pengambilan total sampling karena jumlah populasi kurang dari 100, sehingga seluruh populasi dijadikan sampel pada penelitian (Sugiyono, 2017).

\section{Pengembangan Instrumen dan Teknik Pengumpulan Data}

Instrumen penelitian ini menggunakan data rekam medis pasien dengan lembar observasi. Lembar observasi ini akan disalin dalam bentuk google form untuk mempermudah saat pendataan. Google Form digunakan untuk mengumpulkan data 


\section{Putu Dian Prima Kusuma Dewi, Lina Anggaraeni Dwijayanti, Kadek Ayu Suarmini, Ni Made Karlina Sumiari Tangkas, Indrie Lutfiana, Dewa Ayu Dian Purnami}

rekam medis yang ada sehingga membantu dalam proses analisisnya

Jenis data yang dikumpulkan

Jenis data yang dikumpulkan adalah data sekunder. Data sekunder meliputi data identitas responden (umur ibu, umur kehamilan, pendidikan, pekerjaan, umur kehamilan, indikasi medis, hasil rapid test dan hasil swab PCR pada ibu bersalin).Sebelum data dikumpulkan dilakukan pengurusan kelayakan etik penelitian (Ethical Clearance) melalui KEPK STIKes Buleleng dengan no surat etika clearance yaitu 160/EC-KEPK$\mathrm{SB} / \mathrm{XI} / 2020$

\section{Teknik Analisis Data}

Data kuantitatif dianalisis dengan analisis deskriptif secara univariat bertujuan untuk menjelaskan atau mendeskripsikan karateristik setiap variabel penelitian. Setelah data dianalisis kemudian dimasukkan ke dalam dummy tabel (master tabel) dan dihitung persentasenya. Data yang sudah diolah akan disajikan dalam bentuk tabel distribusi frekuensi dan dalam bentuk narasi. Karakteristik variabel yang dideskripsikan pada penelitian ini adalah karakteristik gestasional ibu bersalin yang meliputi umur ibu, pendidikan, pekerjaan, umur kehamilan, indikasi medis, keluhan, dan hasil rapid test dan swab test PCR Covid 19.

Data kualitatif dianalisis menggunakan metode deksriptif sesuai pemarapan dan hasil wawancara terhadap beberapa informan menggunakan bantuan software INVIVO. Hasil yang diperoleh berupa copy transkrip yang terekam pada responden.

\section{HASIL DAN PEMBAHASAN}

Karakteristik ibu yang melahirkan dengan tindakansectio caesarea berdasarkan umur yaitu rata-rata pada umur 29,77 tahun.

Karakteristik ibu yang melahirkan dengan tindakansectio caesarea berdasarkan umur kehamilan yaitu rata-rata pada umur kehamilan 38,37 minggu.

Tabel 1 menunjukan bahwa karakteristik ibu yang melahirkan dengan tindakansectio caesarea berdasarkan pendidikan ibu lebih banyak pada ibu yang berpendidikan SMA yaitu sebanyak 78 orang (76,47\%), kemudian Perguruan Tinggi sebanyak 13 orang $(12,75 \%)$ dan paling sedikit berpendidikan SMP sebanyak 11 orang $(10,78 \%)$
Tabel 1.

Distribusi ibu melahirkan dengan tindakan

Sectio Caesaria berdasarkan pendidikan $\mathrm{Di}$ RSUD Sanjiwani Gianyar tahun 2020

\begin{tabular}{lcc}
\hline Pendidikan ibu & Frekuensi & Persentase (\%) \\
\hline SD & 0 & 0 \\
SMP & 11 & 10,78 \\
SMA & 78 & 76,47 \\
PT & 13 & 12,75 \\
\hline \multicolumn{1}{c}{ Jumlah } & 102 & 100 \\
\hline
\end{tabular}

Tabel 2.

Distribusi ibu melahirkan dengan tindakan Sectio Caesaria berdasarkan pekerjaan Di RSUD Sanjiwani Gianyar tahun 2020

\begin{tabular}{lcc}
\hline Pekerjaan ibu & Frekuensi & Persentase (\%) \\
\hline Tidak Bekerja & 55 & 53,92 \\
bekerja & 47 & 46,08 \\
\hline \multicolumn{1}{c}{ Jumlah } & 102 & 100 \\
\hline
\end{tabular}

Tabel 2 menunjukan bahwa karakteristik ibu yang melahirkan dengan tindakansectio caesarea berdasarkan pekerjaan ibu, lebih banyak terjadi pada ibu yang tidak bekerja yaitu sebanyak 55 orang $(53,92 \%)$ dan ibu yang bekerja sebanyak 47 orang $(46,08 \%)$

Tabel 3.

Distribusi ibu melahirkan dengan tindakan Sectio Caesaria berdasarkan Umur kehamilan Di RSUD Sanjiwani Gianyar tahun 2020

\begin{tabular}{ccc}
\hline $\begin{array}{c}\text { Umur } \\
\text { kehamilan }\end{array}$ & Frekuensi & $\begin{array}{c}\text { Persentase } \\
(\%)\end{array}$ \\
\hline $28-36$ minggu & 3 & 2,94 \\
$37-40$ minggu & 76 & 74,51 \\
$>40$ minggu & 23 & 22,55 \\
\hline Jumlah & 102 & 100,0 \\
\hline
\end{tabular}

Tabel 3 menunjukan bahwa karakteristik ibu yang melahirkan dengan tindakansectio caesarea berdasarkan umur kehamilan ibu lebih banyak pada kelompok umur kehamilan 37-40 minggu yaitu sebanyak 76 orang $(74,51 \%)$. Kemudian kelompok umur kehamilan $>40$ minggu sebanyak 23 orang $(22,55 \%)$ dan paling sedikit pada kelompok umur kehamilan 28-36 minggu yaitu 3 orang $(2,94 \%)$

Tabel 4 menunjukan bahwa karakteristik ibu yang melahirkan dengan tindakansectio caesarea berdasarkan indikasi medis yaitu 101 orang $(99,02 \%)$ dimana hampir seluruh ibu bersalin dilakukan tindakan sectio caesaria dengan adanya indikasi medis. 
Tabel 4.

Distribusi ibu melahirkan dengan tindakan Sectio Caesaria berdasarkan Indikasi medis Di RSUD Sanjiwani Gianyar tahun 2020

\begin{tabular}{lcc}
\hline \multicolumn{1}{c}{ Indikasi } & Frekuensi & $\begin{array}{c}\text { Persentase } \\
(\mathbf{\%})\end{array}$ \\
\hline $\begin{array}{l}\text { Ada indikasi medis } \\
\text { Tidak ada indikasi }\end{array}$ & 82 & 80.39 \\
medis & 20 & 19.61 \\
\hline \multicolumn{1}{c}{ Jumlah } & 102 & 100,0 \\
\hline
\end{tabular}

Tabel 5.

Distribusi ibu melahirkan dengan tindakan Sectio Caesaria berdasarkan Keluhan Di RSUD Sanjiwani Gianyar tahun 2020

\begin{tabular}{lcc}
\hline Keluhan & Frekuensi & $\begin{array}{c}\text { Persentase } \\
(\%)\end{array}$ \\
\hline $\begin{array}{l}\text { Sakit perut hilang } \\
\text { timbul }\end{array}$ & 31 & 30,39 \\
$\begin{array}{l}\text { Keluar air } \\
\text { pervaginam } \\
\text { (KPD) }\end{array}$ & 33 & 32,35 \\
$\begin{array}{l}\text { Keluar darah } \\
\text { pervaginam }\end{array}$ & & \\
$\begin{array}{l}\text { Gerakan janin } \\
\text { berkurang }\end{array}$ & 1 & 3,92 \\
Tidak ada & & 0,98 \\
keluhan/elektif & 20 & 19,61 \\
Kala II Lama & 2 & 1,96 \\
HIV & 3 & 2,94 \\
$\begin{array}{l}\text { Gagal Drip } \\
\text { Kelainan Letak }\end{array}$ & 2 & 1,96 \\
HT/DM & 5 & 4,90 \\
\hline \multicolumn{1}{c}{ Jumlah } & 1 & 0,98 \\
\hline
\end{tabular}

Tabel 5 menunjukan bahwa karakteristik ibu yang melahirkan dengan tindakansectio caesarea berdasarkan keluhan sebagian besar memiliki keluhan keluar air pervaginam sebanyak 33 orang $(32,35 \%)$

Tabel 6.

Distribusi ibu melahirkan dengan tindakan Sectio Caesaria berdasarkan Hasil rapid test Di RSUD Sanjiwani Gianyar tahun 2020

\begin{tabular}{lcc}
\hline Hasil rapid & Frekuensi & $\begin{array}{c}\text { Persentase } \\
(\%)\end{array}$ \\
\hline $\begin{array}{l}\text { Rapid Test } \\
\begin{array}{l}\text { Positif } \\
\text { Rapid Test }\end{array}\end{array}$ & 37 & 36,27 \\
Negatif & 65 & 63,73 \\
\hline Jumlah & 102 & 100,0 \\
\hline
\end{tabular}

Tabel 6 menunjukan bahwa ibu yang melahirkan dengan tindakan sectio caesaria sebagian besar mempunyai hasil rapid test negative 65 orang $(63,73 \%)$ dan 37 orang $(36,27 \%)$ dengan hasil rapid test positif.

Tabel 7

Distribusi ibu melahirkan dengan tindakan Sectio Caesaria berdasarkan Hasil Swab test PCR Di RSUD Sanjiwani Gianyar tahun 2020

\begin{tabular}{lcc}
\hline $\begin{array}{c}\text { Hasil Swab } \\
\text { PCR }\end{array}$ & Frekuensi & $\begin{array}{c}\text { Persentase } \\
(\%)\end{array}$ \\
\hline Swab PCR & 33 & 32,35 \\
Positif & & 67,65 \\
Swab PCR & 69 & 100 \\
\hline Negatif & 102 & \\
\hline Jumlah & &
\end{tabular}

Tabel 7 menunjukan bahwa sebagian besar ibu bersalin dengan sectio caesaria memiliki hasil Swab PCR negative yaitu 69 orang $(67,65 \%)$ dan 33 orang dengan Swab PCR positif (32,35\%)

Tabel 8.

Karakteristik Gestasi Ibu Bersalin dengan COVID-19 Di RSUD Sanjiwani Gianyar, September-Desember 2020

\begin{tabular}{lcccc}
\hline \multirow{2}{*}{ Karakteristik Gestasi } & \multicolumn{2}{c}{ Rapid Test } & \multicolumn{2}{c}{ Swab } \\
\cline { 2 - 5 } & Reaktif & Non Reaktif & Positif & Negatif \\
\cline { 2 - 5 } & $\mathbf{f ( \% )}$ & $\mathbf{f}(\%)$ & $\mathbf{f}(\%)$ & $\mathbf{f}(\%)$ \\
\hline Umur & 29,81 & 29,75 & 30,15 & 29,59 \\
Umur Kehamilan & 38,24 & 38,44 & 38,30 & 38,40 \\
Pendidikan & & & & \\
SMP & $2(5,41)$ & $9(13,85)$ & $1(3,03)$ & $10(14,49)$ \\
SMA & $30(81,08)$ & $48(73,85)$ & $27(81,82)$ & $51(73,91)$ \\
PT & $5(13,51)$ & $8(12,31)$ & $5(15,15)$ & $8(11,59)$ \\
Pekerjaan & & & &
\end{tabular}




\section{Putu Dian Prima Kusuma Dewi, Lina Anggaraeni Dwijayanti, Kadek Ayu Suarmini, Ni Made Karlina Sumiari Tangkas, Indrie Lutfiana, Dewa Ayu Dian Purnami}

\begin{tabular}{lcccc} 
Tidak Bekerja & $19(51,35)$ & $36(55,38)$ & $16(48,48)$ & $39(56,62)$ \\
Bekerja & $18(48,65)$ & $29(44,62)$ & $17(51,52)$ & $30(43,48)$ \\
Keluhan & & & & \\
Sakit perut hilang timbul & $14(37,84)$ & $19(29,23)$ & $12(36,36)$ & $21(30,43)$ \\
Keluar air pervaginam (KPD) & $15(40,54)$ & $16(24,62)$ & $13(39,39)$ & $18(26,09)$ \\
Keluar darah pervaginam & $1(2,70)$ & $3(4,62)$ & $1(3,03)$ & $3(4,35)$ \\
Gerakan janin berkurang & $1(2,70)$ & $0(0,00)$ & $1(3,03)$ & $0(0,00)$ \\
Tidak ada keluhan/operasi elektif & $4(10,81)$ & $16(24,62)$ & $4(12,12)$ & $16(23,19)$ \\
kala II Lama & $1(2,70)$ & $1(1,54)$ & $1(3,03)$ & $1(1,45)$ \\
HIV & $0(0,00)$ & $3(4,62)$ & $0(0,00)$ & $3(4,35)$ \\
gagal drip/kejang & $0(0,00)$ & $2(3,08)$ & $0(0,00)$ & $2(2,90)$ \\
kelainan letak & $1(2,70)$ & $4(6,15)$ & $1(3,03)$ & $4(5,80)$ \\
HT/DM & $0(0,00)$ & $1(1,54)$ & $0(0,00)$ & $1(1,45)$ \\
Indikasi Medis & & & & \\
Ada Indikasi Medis & $37(100)$ & $64(98,46)$ & $33(100)$ & $68(98,55)$ \\
Tidak ada Indikasi Medis & $0(0,00)$ & $1(1,54)$ & $0(0,00)$ & $1(1,45)$ \\
\hline
\end{tabular}

Tabel 8 menunjukkan rata-rata pasien yang melahirkan dengan hasil rapid test positif adalah umur 29.81 tahun dan rata-rata melahirkan dalam umur kehamilan 38.24 minggu. Pada ibu bersalin dengan hasil rapid test positif sebagian besar mempunyai pendidikan SMA yaitu 30 orang $(81,08 \%)$ dan mayoritas dalam kategori tidak bekerja 19 orang $(51,35 \%)$. Keluhan yang paling banyak dialami adalah keluar air pervaginam (KPD) sebanyak 15 orang $(40,54 \%)$ dan seluruh ibu bersalin dengan hasil rapid test positif dilakukan tindakansectio caesarea dengan indikasi medis $(100 \%)$.

Rata-rata pasien yang melahirkan dengan hasil Swab Test PCR positif adalah umur 30.15 tahun dan rata-rata melahirkan dalam umur kehamilan 38.30 minggu. Pada ibu bersalin dengan hasil Swab Test PCR positif sebagian besar mempunyai pendidikan SMA yaitu 27 orang $(81,82 \%)$ dan mayoritas dalam kategori bekerja 17 orang $(51,52 \%)$. Keluhan yang paling banyak dialami adalah keluar air pervaginam (KPD) sebanyak 13 orang $(39,39 \%)$ dan seluruh ibu bersalin dengan hasil Swab Test PCR positif dilakukan tindakansectio caesarea dengan indikasi medis (100\%).

Hasil data secara kualitatif diperoleh yaitu Informan 1 "Semua ibu bersalin wajib dilakukan rapid test, ketika rapid test dinyatakan positif maka dilanjutkan swab test. Ibu bersalin yang dinyatakan positif wajib menjalani perawatan dalam ruang isolasi. Jika ada indikasi atau masalah maka tidakan SC akan egera dilakukan"

Informan 2 "Ibu bersalin sesuai protap akan dilakukan test 2 minggu sebelum bersalin sehingga persiapan persalinan dapat dilakukan dengan baik. Tim kami selalu berusaha mengutamakan keselamatan ibu dan bayi yang akan dilahirkan, jadi kalua ibu berslain nya gkada masalah apapun diusahakan pasti normal dengan APD level 3 yang maksimal"

Informan 3 " Dilema sekali ya, tentu ada rasa panik apalagi saat pertama menangani pasien bersalin dengan Covid 19. SC memang piihan akhir tetapi SC menjadi jalan yang paling aman utamanya untuk keselamatan bayi yang dilahirkan. Tapi seiring dengan banyaknya pelatihan terkait penanganan layanan KIA di masa pandemic ini rasanya anatara regulasi dan protap yang ada sudah selalu disesuiakan agar selalu mengutamakan keselamatan pasien dan tenaga kesehatan"

\section{PEMBAHASAN}

Karakteristik ibu yang melahirkan dengan tindakansectio caesarea berdasarkan umur yaitu rata-rata pada umur 29,77 tahun. Pada usia ini responden secara kematangan reproduksi sudah siap untuk pembuahan. Selain itu, pada usia tersebut ibu dalam kategori aman dalam menjalani kehamilan dan persalinan. Menurut Saifuddin 2009 (dalam Trivoni, 2012) dikatakan bahwa usia 20-35 tahun merupakan usia reproduksi wanita, dimana diusia tersebut seorang ibu mampu hamil dalam kondisi yang sehat baik fisik maupun psikologis. Pada ibu hamil usia ini dianggap ideal untuk menjalani kehamilan dan proses persalinan.

Karakteristik ibu yang melahirkan dengan tindakansectio caesarea berdasarkan umur kehamilan yaitu rata-rata pada umur kehamilan 38,37 minggu. Ibu bersalin secara normal akan melahirkan saat usia kehamilan aterem atau usia kehamilan 37-40 minggu. Dimana pada masa ini perkembangan dan pertumbuhan janin sudah sempurna dan sudah siap untuk bisa hidup diluar kandungan. Bayi yang lahir saat usia kandungan 


\section{JKM (Jurnal Kebidanan Malahayati),Vol 7,No.3.Juli 2021, ISSN (Print) 2476-8944 ISSN (Online) 2579-762X, Hal 471-480}

1>37 minggu (premature) biasanya paru-parunya belum matang secara sempurna sehingga bayi bisa mengalami gangguan saat bernafas. Bayi yang lahir pada usia kehamilan $>42$ minggu biasanya ada masalah pada plasenta dimana plasentanya mengalami kalsifikasi dan pada bayi biasanya mengalami kulit kering dan keriput (Varney, Kriebs and Gregor, 2008; Fraser, 2011). Bayi yang lahir saat usia kehamilan aterm memiliki perkembangan yang sempurna dan sudah siap dilahirkan secara sempurna. Usia kehamilan juga memiliki risiko menyebabkan kehamilan yang berisiko bahkan sampai menyebabkan kematian pada bayi. Menurut Ahmad (2016) menyatakan bahwa factor resiko terjadinya abortus di RS adalah usia kehamilan. Ibu hamil yang memasuki trimester I mempunyai risiko abortus 19.7 kali lebih besar dibandingkan dengan ibu yang sudah melewati usia kehamilan trimester I.

Pendidikan mayoritas ibu bersalin adalah SMA yaitu sebanyak 78 orang $(76,47 \%)$. Pendidikan menentukan mudah tidaknya seseorang menyerap dan memahami pengetahuan yang diperoleh, pada umumnya semakin mtinggi pendidikan seseorang makan semakin tinggi pula pengetahuannya. Menurut Notoatmodjo (2007), semakin tinggi tingkat pendidikan seseorang, maka semakin mudah menerima informasi sehingga semakin banyak pula pengetahuan yang dimiliki. Seseorang yang memiliki pendidikan tinggi akan dapat mengambil keputusan yang lebih rasional, dan umumnya lebih terbuka untuk menerima perubahan atau hal yang baru.

Hasil penelitian menunjukkan sebagian besar responden tidak bekerja adalah sebanyak 55 orang $(53,92 \%)$. Pekerjaan merupakan salah satu penyebab dilakukannya tindakan caesar dalam proses persalinan, ibu yang memiliki pekerjaan berat selama kehamilan, besar kemungkinan akan mengalami komplikasi pada kehamilannya. Ibu yang bekerja rentan mengalami trauma seperti terbentur atau terjatuh akibat melakukan pekerjaan yang berat sehingga mempengaruhi kehamilan dan persalinannya, salah satunya adalah ruptura uteri yang terjadi pada ibu dengan riwayat Sectio Caesarea. Lain halnya pada ibu yang tidak bekeja, karena memiliki banyak waktu untuk menjaga kesehatan dan kehamilannya dan risiko untuk mengalami trauma lebih sedikit, hal ini disebabkan karena aktifitas ibu tidak terlalu padat dan dapat mengontrol waktu untuk beristirahat. Pekerjaan dalam hal ini juga dapat mempengaruhi ibu bersalin dalam melakukan perawatan selama masa bersalin pada ibu post SC, dimana ibu yang bekerja akan mudah mendapatkan informasi dibandingkan dengan ibu yang tidak bekerja. Pada ibu yang tidak bekerja, kemungkinan besar memiliki waktu yang cukup banyak untuk mencari informasi dan mendatangi faslitas kesehatan untuk melakukan konsultasi mengenai perawatan diri selama masa bersalin SC. Sedangkan pada ibu yang bekerja kemungkinan tidak memiliki waktu luang yang cukup untuk mencari infromasi yang disebabkan karena terbatasnya waktu akibat jam kerja yang padat.

Hasil penelitian menunjukkan sebagian besar ada indikasi medis 101 orang (99,02\%). Indikasi Medis bermacam-macam variasi yang terdapat pada proses tindakan Sectio caesaria seperti KPD $>12$ jam dan Partus tidak maju. KPD bisa menyebabkan infeksi pada ibu bersalin dan bayi karena pecah ketuban merupakan salah satu media yang bisa mengantarkan virus/bakteri dari luar ke dalam kandungan(Dini, 2012; Triguno et al., 2020). Air ketuban juga mempengaruhi kesejahteraan bayi di dalam kandungan, dimana jumlah air ketuban yang sedikit bisa menyebabkan bayi mengalami gawat janin. faktor lain yang menyebabkan persalinan dilakukan dengan tindakan SC yaitu Partus lama. Partus lama juga merupakan bagian dari faktor penyebab gawat janin atau fetal distress. Menurut Prawirahadjo (2009) bahwa proses persalinan lama selalu memberikan dampak yang buruk dan penyulit bagi ibu dan janin yang sedang dikandungnya. Janin dalam rahim menjadi dalam situasi berbahaya karena kontraksi rahim terjadi 24 jam yang dapat mengganggu aliran darah menuju janin. Menurut Kemenkes (2018) faktor penyebab terjadinya gawat janin yaitu persalinan lama, perdarahan, kejang, obat perangsang kontraksi rahim, infeksi, kehamilan prematur dan post matur, ketuban pecah lama dan tali pusat menumbung. Menurut Sumelung (2014) bahwa indikasi yang sering menyebabkan kejadian sectio caesarea yaitu gawat janin sebanyak 52 responden $(31,14 \%)$. Gawat janin merupakan salah satu indikasi yang sering terjadi pada ibu persalinan sectio caesarea, jika ibu dengan gawat janin tetap melakukan partus normal maka akan membahayakan keselamatan ibu dan bayi. Menurut Adrian (2019) bahwa persalinan yang terlalu lama bukan hanya dapat menguras tenaga, tapi juga berbahaya bagi kondisi ibu dan janin di dalam kandungan. Proses persalinan yang macet ini bisa menyebabkan ibu kelelahan, serta meningkatkan risiko bayi mengalami gawat janin, cedera, dan infeksi. Kondisi persalinan lama dapat menyebabkan kurangnya pasokan oksigen pada janin sehingga bersiko menyebabkan fetal distress. Kemenkes (2018) bahwa fetal distress merupakan kondisi janin mengalami kekurangan menerima $\mathrm{O}$, 


\section{Putu Dian Prima Kusuma Dewi, Lina Anggaraeni Dwijayanti, Kadek Ayu Suarmini, Ni Made Karlina Sumiari Tangkas, Indrie Lutfiana, Dewa Ayu Dian Purnami}

sehingga janin mengalami sesak. Pernyataan diatas juga dikuatkan pendapat Reiter dan Walsh (2010) menyebutkan bahwa persalinan yang berlangsung lama memiliki risiko untuk menyebabkan kejadian fetal distress pada bayi. Federico dan Staton (2018) bahwa persalinan yang lama dan persalinan yang sulit menempatkan ibu pada risiko bahaya serius, tetapi keadaan ini juga dapat menciptakan gawat janin yang akan berefek pada jangka panjang bagi kesehatan dan perkembangan bayi baru lahir itu sediri. Ada sejumlah cacat jangka panjang yang bisa diakibatkan oleh gawat janin.

Hasil penelitian menunjukkan sebagian besar memiliki keluhan keluar air pervaginam (KPD) yaitu 33 orang (32,35\%). Secara teori ketuban pecah dini menyebabkan slah satu factor hubungan langsung antara dunia luar dan ruangan dalam Rahim segingga memudahkan terjainya infeksi asenden. Makin lama periode laten makin besar infeksi dalam Rahim, persalinan prematuritas dan selanjutnya meningkatkan kejadian kesakitan dan kemaitn ibu atau janin dalam Rahim (Manuaba, 2012). Dengan kemungkinan adanya factor resiko tersebut maka sebaiknya dilakukan tindakana section cesaria. Hal ini didukung oleh penelitian (Fitri, Ayuni,2017) yang meneliti tentang factorfaktor yang berhubungan dengan terjadinya persalinansectio caesarea di RSUD Rantau Prapat, terdapat 20 responden $(13,2 \%)$ terjadi ketuban pecah dini.

Selama menghadapi pandemic COVID-19, setiap rumah sakit sudah mempersiapkan persalinan yang aman untuk ibu yang akan melahirkan. Setiap ibu yang akan melahirkan diwajibkan melakukan rapid test untuk dilakukan screening COVID-19. Apabila hasil rapid test reaktif, ibu hamil akan ditempatkan diruangan isolasi untuk mencegah terjadinya penularan kepada pasien yg lain. Ibu hamil dengan test rapid reaktif akan dilakukan pemeriksaan lanjutan yaitu swab test PCR. Ibu bersalin dengan rapid test reaktif akan dilakukan tindakan sectio caesaria dengan pertimbangan untuk mempercepat proses melahirkan dan meminimalisasi penularan COVID19 dari pasien terkontaminasi ke penolong persalinan ataupun pasien bersalin yang lain yang berada dalam ruangan yang sama. Covid-19 merupakan virus baru dan pandemic terjadi belum setahun, jadi belum ada penelitian yang sama yang mendukung penelitian ini.

Hasil penelitian menunjukkan hasil Swab PCR positif 33 orang $(32,35 \%)$ dan swab PCR negatif sebanyak 69 orang $(67,65 \%)$. Ibu bersalin yang sudah terkonfirmasi covid-19 akan dikarantina di bapelkes atau tempat karantina khusus seperti hotel dan diawasi oleh petugas kesehatan. Saat pasien mengalami tanda gejala melahirkan, pasien akan segera dibawa ke rumah sakit rujukan covid oleh tim PSC dan akan segera dilakukan tindakansectio caesarea untuk meminimalisir terjadinya penularan covid-19 dari pasien ke penolong persalinan. Berdasarkan studi epidemiologi dan virologi saat ini membuktikan bahwa COVID-19 utamanya ditularkan dari orang yang bergejala (simptomatik) ke orang lain yang berada jarak dekat melalui droplet. Droplet merupakan partikel berisi air dengan diameter $>5$ $10 \mu \mathrm{m}$. Penularan droplet terjadi ketika seseorang berada pada jarak dekat (dalam 1 meter) dengan seseorang yang memiliki gejala pernapasan (misalnya, batuk atau bersin) sehingga droplet berisiko mengenai mukosa (mulut dan hidung) atau konjungtiva (mata). Penularan juga dapat terjadi melalui benda dan permukaan yang terkontaminasi droplet di sekitar orang yang terinfeksi. Oleh karena itu, penularan virus Covid-19 dapat terjadi melalui kontak langsung dengan orang yang terinfeksi dan kontak tidak langsung dengan permukaan atau benda yang digunakan pada orang yang terinfeksi (misalnya, stetoskop atau termometer) (Handayani et al., 2020). WHO merekomendasikan pemeriksaan molekuler untuk seluruh pasien yang terduga terinfeksi Covid 19. Metode yang dianjurkan adalah metode deteksi molekuler/NAAT (Nucleic Acid Amplification Test) seperti pemeriksaan RTPCR (swab).

Rata-rata ibu yang melahirkan dengan hasil rapid test positif adalah umur 29.81 tahun dan ratarata melahirkan dalam umur kehamilan 38.24 minggu. Pada ibu bersalin dengan hasil rapid test positif sebagian besar mempunyai pendidikan SMA yaitu 30 orang $(81,08 \%)$ dan mayoritas dalam kategori tidak bekerja 19 orang $(51,35 \%)$. Keluhan yang paling banyak dialami adalah keluar air pervaginam (KPD) sebanyak 15 orang $(40,54 \%)$ dan seluruh ibu bersalin dengan hasil rapid test positif dilakukan tindakansectio caesarea dengan indikasi medis $(100 \%)$. Pemeriksaan rapid test untuk screening COVId-19 dilakukan mulai bulan Juni-Desember 2020. Tujuaanya adalah meminimalisir penularan penyakit dari pasien ke pasien dan ke tenaga kesehatan. Setiap pasien dengan hasil rapid positif akan segera dilakukan timdakansectio caesarea dan setelah melahirkan ditempatkan di ruangan isolasi beserta bayinya sambil menunggu jadwal swab dan hasil swab PCR. Apabila hasil swab negative, ibu dan bayi akan dipindah ke ruangan nifas dan apabila hasil swab positif, ibu akan tetep dirawat di ruangan khusus covid dan akan dikonsulkan ke spesialis 
paru. Bayi dengan hasil swab negative akan dipisahkan dari ibunya yang hasil swab positif.

Memasuki tahun 2021, di RSUD Sanjiwani Gianyar sudah disiapkan rapid test antigen, dimana rapid test antigen ini mempunyai keakuratan yang lebih tinggi dibandingkan rapid test antibody. Keunggulan rapid test antigen diantaranya dapat medeteksi virus secara langsung dan bisa dilakukan lebih cepat dari PCR. Oleh karena itu, test cepat antigen menjadi pilihan karena dapat dilaksnakan dengan cepat dengan tingkat kepercayaan dibawah PCR.(RS Sanjiwani, 2020)

Pasien dengan hasil rapid test positif akan dilanjutkan dengan swab test PCR. Rata-rata pasien yang melahirkan dengan hasil Swab Test PCR positif adalah umur 30.15 tahun dan rata-rata melahirkan dalam umur kehamilan 38.30 minggu. Pada ibu bersalin dengan hasil Swab Test PCR positif sebagian besar mempunyai pendidikan SMA yaitu 27 orang $(81,82 \%)$ dan mayoritas dalam kategori bekerja 17 orang (51,52\%). Keluhan yang paling banyak dialami adalah keluar air pervaginam (KPD) sebanyak 13 orang $(39,39 \%)$ dan seluruh ibu bersalin dengan hasil Swab Test PCR positif dilakukan tindakansectio caesarea dengan indikasi medis (100\%). Untuk saat ini, screening COVID-19 yang paling akurat adalah dengan metode PCR. Setiap pasien hamil yang sudah terkonfirmasi COVID-19 dengan metode PCR akan segera dilakukan tindakansectio caesarea. Ibu nifas dengan hasil swab PCR positif juga akan diberikan KIE untuk selalu menjaga protocol kesehatan dan tidak menyusui bayinya. Mulai bulan Januari 2021, setiap pasien dengan hasil rapid antigen positif atau sudah terkonfimasi COVID-19 akan diusahakan untuk bisa melahirkan normal. Tindakansectio caesarea hanya dilakukan jika ada penyulit dalam persalinan. Hal ini sesuai dengan kebijakan Pemerintah Daerah dan POGI.

Hasil penelitian ini mampu menampilkan karakteristik gestational layanan ibu bersalin di masa pandemi. Kelemahan dari penelitian ini masih terbatas deskriptif, perlu analisis uji statistic yang lebih lanjut.

\section{SIMPULAN}

Karakteristik ibu yang melahirkan secara sectio caesarea berdasarkan umur rata-rata adalah 29,77 tahun dengan rata-rata umur kehamilan adalah 38,37 minggu. Hasil Swab PCR positif 33 orang $(32,35 \%)$ dan swab PCR negatif sebanyak 4 orang (\%). Hasil kajian ini menjadi gambaran untuk melihat kondisi layanan kesehatan ibu di masa pendemi
Regulasi layanan ibu bersalin pada masa pandemi COVID 19 ini lebih pada skrining yaitu wajib rapid test dan test PCR. Penanganan dengan protokol kesehatan yang ketat level 3 untuk memutus rantai penularan virus.

\section{SARAN}

Regulasi layanan ibu bersalin pada masa pandemi COVID 19 ini lebih pada skrining yaitu wajib rapid test dan test PCR. Penanganan dengan protokol kesehatan yang ketat level 3 untuk memutus rantai penularan virus.

\section{UCAPAN TERIMAKASIH}

Ucapan terimakasih ucapan terimakasih disampaikan kepada Direktur RSU Sanjiwani Gianyar, Ketua STikes Buleleng dan jajaran Pimpinan diRuang IBS dan Ruang VK.

\section{DAFTAR PUSTAKA}

Dini, P. (2012) 'Preterm Usia Kehamilan 34-36 Minggu Dengan Dan'.

Fraser, D. (2011) Buku Ajar Bidan. I. Jakarta: ECG.

Gugus Tugas Percepatan Penanganan COVID-19 (2020) 'Protokol Petunjuk Praktis Layanan Kesehatan Ibu dan Bayi Baru Lahir Selama Pandemi COVID-19', Protokol Gugus Tugas Percepatan Penanganan Covid-19 Ri, 4(April), pp. 1-11. Available at: https://covid19.go.id/p/protokol/protokol-b-4petunjuk-praktis-layanan-kesehatan-ibu-danbbl-pada-masa-pandemi-covid-19.

Handayani, D. et al. (2020) 'Corona Virus Disease 2019', Jurnal Respirologi Indonesia, 40(2), pp. 119-129.

Karimi, L. et al. (2021) 'Effect of COVID-19 on Mortality of Pregnant and Postpartum Women: A Systematic Review and MetaAnalysis', Journal of Pregnancy, 2021, pp. 1-33. doi: $10.1155 / 2021 / 8870129$.

Kemenkes, R. (2020) Pedoman Pencegahan Dan Pengendalian Coronavirus Disesase (Covid19) Revisi V. Edited by S. dr. Listiana Aziza, Sp.KP; Adistikah Aqmarina, SKM; Maulidiah Ihsan. Jakarta: Jakarta: Kementrian Kesehatan Republik Indonesia.

Schwartz, D. A. and Graham, A. L. (2020) 'Potential maternal and infant outcomes from coronavirus 2019-NCOV (SARS-CoV-2) infecting pregnant women: Lessons from SARS, MERS, and other human coronavirus infections', Viruses, 12(2), pp. 1-16. doi: 10.3390/v12020194.

Triguno, Y. et al. (2020) 'Faktor Risiko Kelainan Letak Pada Ibu Hamil: Studi Karakteristik 


\section{Putu Dian Prima Kusuma Dewi, Lina Anggaraeni Dwijayanti, Kadek Ayu Suarmini, Ni Made Karlina Sumiari Tangkas, Indrie Lutfiana, Dewa Ayu Dian Purnami}

Gestasi Pada Rumah Sakit Swasta Di Kabupaten Buleleng , Ball', 6(2), pp. 186189.

Varney, H., Kriebs, J. M. and Gregor, C. L. (2008) Buku Ajar Asuhan Kebidanan, vol 2. Jakarta: EGC.

World Health Organization (2020) Global surveillance for human infection with novelcoronavirus(2019-ncov).

Dinas Kesehatan Provinsi Bali. 2020.

Gugus Tugas Percepatan Penganan Corona Virus Disease 2019 (Covid 19) Provinsi Bali. Denpasar: Dinas Kesehatan Provinsi Bali

Doremalen N, Bushmaker T, Morris DH, Holbrook MG, Gamble A, W. B. 2020. Aerosol and Surface Stability of SARS-CoV-2 as Compared with SARS-CoV-1. Engl J Med, 16(382), 1564-156.

Du Z, Xu X, Wu Y, Wang L, Cowling BJ, M. LA. 2020. Serial interval of COVID-19 among publicly reported confirmed cases. Emerging infectious diseases. 26(6).

Handayani, D., Hadi, D. R., Isbaniah, F., Burhan, E., \& Agustin, H. 2020. Corona Virus Disease 2019. Jurnal Respirologi Indonesia, 40(2), 119-129.

Hidayat, A. A. (2011). Metode Penelitian Kesehatan Paradigma Kuantitatif. Surabaya: Health Books Publishing

Heffner, Linda J \& Schrust DJ. At a glance sistem reproduksi. Edisi Kedu. Jakarta: Erlangga Medical Series; 2010.

Kang, L., Li, Y., Hu, S., Chen, M., Yang, C., Yang, B. 2020. The mental health of medical workers in Wuhan, China dealing with the 2019 novel coronavirus. The Lancet Psychiatry, $7(3)$. https://doi.org/10.1016/S22150366(20)30047-X

Kemenkes, RI. 2020. Pedoman Pencegahan Dan Pengendalian Coronavirus Disesase (COVID-19) Revisi V (S. dr. Listiana Aziza, Sp.KP; Adistikah Aqmarina, SKM; Maulidiah Ihsan (ed.)). Jakarta: Kementerian Kesehatan Republik Indonesia.
Rumah Sakit Sanjiwani.2020. Spo Pendampingan Pasien Covid-19 di Ruangan Isolasi

Saifuddin, AB. 2001. Buku Panduan Praktis Pelayanan Kesehatan Maternal dan Neonatal. Edisi I. Jakarta: Yayasan Bina Pustaka Sarwono Prawiroharjo

Saifullah, A. 2015. Hubungan Tingkat Pengetahuan Perawat dengan Tindakan Perawat dalam Managemen Nyeri Post Operasi di Bangsal Bedah RSUD DR Suehadi Prijonegoro Sragen.

Sukarni, I dan Margareth, Z.H. (2013). Kehamilan, Persalinan dan Nifas, Yogyakarta: Nuha Medika

Sukarni, I dan Wahyu, P. (2013). Buku Ajar Keperawatan Maternitas, Yogyakarta: Nuha Medika

Sumarah. \& Marianingsih, E. dkk. (2013). Pengaruh mobilisasi dini terhadap penyembuhan luka post sectio caesarea.

Swarjana, K. I.,(2015) Metodologi Penelitian Kesehatan (Edisi Revisi). Yogyakarta: Andi Offset

Walyani, Elisabeth Siwi. 2014. Asuhan Kebidanan pada Kehamilan. Yogyakarta; Pustaka Baru Press.

Whalley, J. 2005. Panduan Cepat Bagi Ibu Hamil dan Bersalin. Cetakan I:Jakarta:PT Bhuana IImu Populer

Widjanarko, M. (2009). Perilaku Seks Remaja. Jurnal Sosial dan Budaya. Volume 2 Nomor 2. Desember ISBN:1979-6889. Kudus: Lembaga Penelitian Universitas Muria Kudus.

World Health Organization. 2020. Global Surveillance For Human Infection With Novel-Coronavirus(2019-ncov).

Wu, P., Fang, Y., Guan, Z., Fan, B., Kong, J., Yao, Z. 2019. The psychological impact of the SARS epidemic on hospital employees in China: exposure, risk perception, and altruistic acceptance of risk. Can J Psychiatry, 54(5), 302-311. https://doi.org/10.1177/07067437090540050 4 